Vincent BATTESTI - The Giza Zoo: Re-Appropriating

Public Spaces, Re-Imagining Urban Beauty,

in Amar P. and Singerman D. (eds), Cairo Cosmopolitan:

Politics, Culture, and Urban space in the New

Globalized Middle East, The American University in

Cairo Press (2006), pp. 489-511.

http://halshs.archives-ouvertes.fr/halshs-00106861

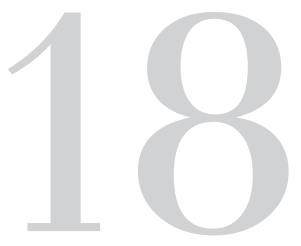

\title{
The Giza Zoo
}

\section{Reappropriating Public Spaces, Reimagining Urban Beauty}

\section{Vincent Battesti}

In what way does the city invite us to believe the world one more time and in another manner? Joseph 1996.

The crowd is dense, circulating around the exhibits, eddying between the monkey cages and the barriers that protect the patches of lawn. It is the second day of post-Ramadan holidays at the Giza Zoo. Hundreds of picnicking families and romantic couples get up from off lawn that is technically 'closed to the public.' Using a thick black hose, a zoo gardener inundates the area with a spray of water. "Move out! Stay outside!" But hardly has he turned his back to pick up some trash, when visitors again cross the border of this little island of green, walking with precaution toward the center of what is now a marsh in the middle of which rises a floral composition of palms and cement. Among the adventurers, two young couples: the boys are carrying cameras, and the two girls wearing head-scarves pick up their long skirts a little in order not to spot them with mud. Together, the two girls pause in front of the palms, but this is only the preliminary to a more studied pose. The competing adolescents are already monopolizing a useful part of the decor (the trunk of a dead tree): "Give me my 
dark glasses for the photo!" One of the couples decides to pose farther away, where the sunlight of the end of the day pierces some foliage. The boy and the girl lean symmetrically on one of the park's floral lamps; the plants form the backdrop. The girl readjusts her blouse, smooths down her dress, straightens the pleats of her skirt and, finally, immobile, both of them look straight ahead at the camera lens. A little ill at ease, the boy only brightens his expression at the instant of the flash. The girl, gently smiling, seems defiant. Following the flash, the pose is kept a few seconds too long. Then all seem relieved.

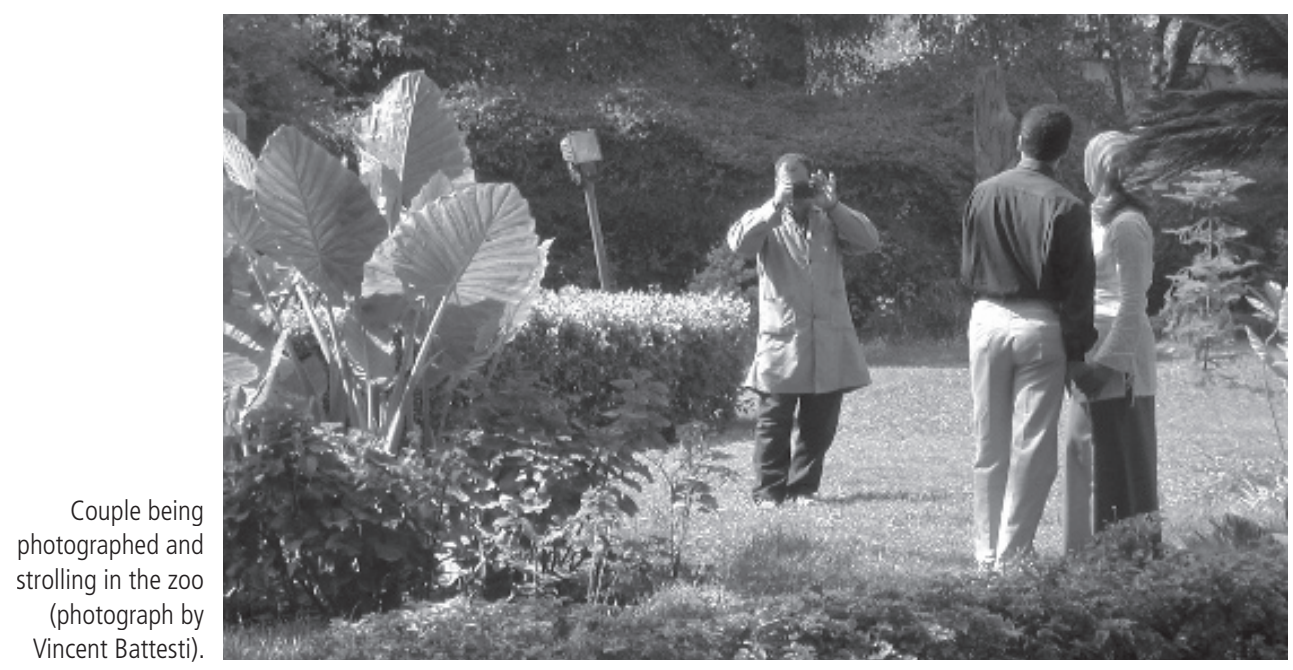

The authorities at the zoo, as in most of the public spaces in Cairo, attempt to control the crowd indirectly, as a herder does his flock, by constructing obstacles such as fences to influence the flow of the crowd. Often, the crowd overflows the authorized bounds of public space. Between the initial statedesignated uses for spaces and their actual arrangements, a process of popular reappropriation has taken place, conforming to the expectations of Cairo's popular classes, and to the values they give to those spaces. The zoo is, at once, the place where masses gather for big festivals, and where couples flirt in a romantic setting. It is this negotiation - the couple extracting itself from the crowd for an instant-that creates the intimacy captured in those cliché photographs that immortalize and attest to a relationship. After the photos, the two couples will cross the symbolic barrier and become anonymous again, as they plunge back into the dense and boisterous crowd.

Undeniably, green spaces provoke public frenzy in Cairo. In accordance with the contemporary desirability of 'quality of life' and its quota of greenery, 
many global cities have arrived at the same solution: create large parks on the periphery of the city. Urban life in Cairo, however, manages to articulate its own local responses. If some green spaces dot the landscape of the city and its suburban area, it is the not-peripheral (and quite green) zoo that the popular classes adore, especially during holidays. The popular passion for the zoo and the way it is used today were not defined in the original vision for this park. Evolving out of the garden of Khedive Isma'il's harem, the Zoological Garden was conceived within the same paradigm as the other gardens of the downtown area. During the nineteenth century, the creation of new spaces corresponded to the globalizing colonial modern urban norms of the period. Rulers of the great capitals focused on opening areas for bourgeois promenades. Over the twentieth century, however, the colonial design for these new public spaces was subverted as the popular strata of society appropriated these spaces for themselves, especially during holidays, transforming the social experience associated with those areas. Meanwhile the wealthier classes increasingly came to prefer private clubs and gated communities. How are the planned uses for these spaces arranged for the disposition of their intended publics? How do norms of behavior in public space adapt to shifts in public frequentation and appropriation? And how is the use of public order imagined and reconfigured by park-users and state authorities?

This chapter discusses certain public spaces in Cairo that respond to the imperatives of spatial openness and accessibility (Beyhum 1997), particularly the zoo at Giza (Hadiqat al-Hayawanat), with some comparison with the popularly claimed areas of wust al-balad, Cairo's central business district. Both spaces are very much frequented by the popular classes according to specific rhythms. These public spaces are where one goes to amuse oneself in a liberated, disinterested, and hedonistic way (a potential definition of 'leisure' that certain authors reserve for postindustrial societies, Dumazedier I998).

In truth, we usually come here to look at the beautiful things that are here, the animals, but also the beautiful girls. The people are beautiful in the way they stroll about. It's beautiful weather out and, in fact, all the people have come today to have fun in the Zoological Garden (student from the American University in Cairo [AUC] at the zoo, 2003).

\section{Festival Day at the Zoological Garden at Giza}

Many of Cairo's residents are familiar with Giza's Zoological Garden only during its most intense moments, when it is festive and frequented by the largest mass of people, although these moments do not represent the 'normal' 
or daily way the space is occupied. "The ambiance is not always like this.... The crowds will decrease, and it will be more charming (AUC student at the zoo, 20O3)."

The three-tiered ladder of usage proposed by visitors to the zoo (weekday, weekend, and festival day) represents a gradient of frequentation and a barometer of holiday ambiance. Festival days are marked by a supplemental degree of intensity that encourages people to test the limits of the use of a public space. The four days that follow the 'Id al-Fitr festival (end of Ramadan) marks an intense period for the zoo since people have been observing Ramadan's daily restrictions for a month. During the 'Id, a carnival atmosphere erupts.

During the day, the unusually deserted streets downtown hardly augur an urban fever elsewhere. But the crowds during these days can all be found at the Giza Zoo. From the opening of the doors at nine o'clock, a crowd gathers at the entrance gates and clamors for tickets. The entrance fee is only twenty-five piasters for Egyptians, Arabs, and foreigners, according to a sign, painted many years ago, at the entrance ticket-offices, and thus it is financially accessible to almost all Cairenes.

Since men seem to take charge of ticket buying, the ticket booth becomes a masculine melee as men pass their money to the women at the cash registers, through the high grates of the enclosure. The guards at the entrance try to organize a circulation of bodies that looks more like an evacuation, but one that is directed toward the interior. Colorful, varied, heterogeneous, dense, agitated, excited crowds fill the interior gardens and pathways of the zoo. The particularity of this holiday season is the large number of children that participate in it. Microbuses and packed carts discharge young boys (from six years of age) into the zoo, without parental control. The Zoological Garden becomes a vast playground. Many families also come to stroll there: married couples, fiancés or the not-yet-engaged, alone or circulating among many. An entire class of the city's inhabitants seems to show up taking only the precaution of leaving the eldest at home.

During these four days of the 'Id of Ramadan, calculations of total visitors vary wildly as bean-counters throw up their hands. "We welcome between three hundred and five hundred thousand visitors each day," noted the director of the Zoological Garden, Mustafa 'Awad (interview, 2003). Certainly, there is agreement that several tens of thousands of visitors must be here. "We made our way through hundreds of thousands of picnickers playing games, singing and dancing” (Shahine I999). The Zoological Garden's pathways teem with people, not a single direction of foot traffic is privileged. The boys move 
about wandering in groups, invading the entire space given over to people, lingering; then suddenly agitated by a brusque change of regime, they run toward the larger crowd increasing its size. The object of these mobs is a fight breaking out, rather then an animal making a show, followed by nothing at all, a nonevent that fed upon the random attention of groups of visitors. The happy groups flow, occupying physical space to its smallest corners, attempting to penetrate the grottos, or spilling onto the forbidden lawns.

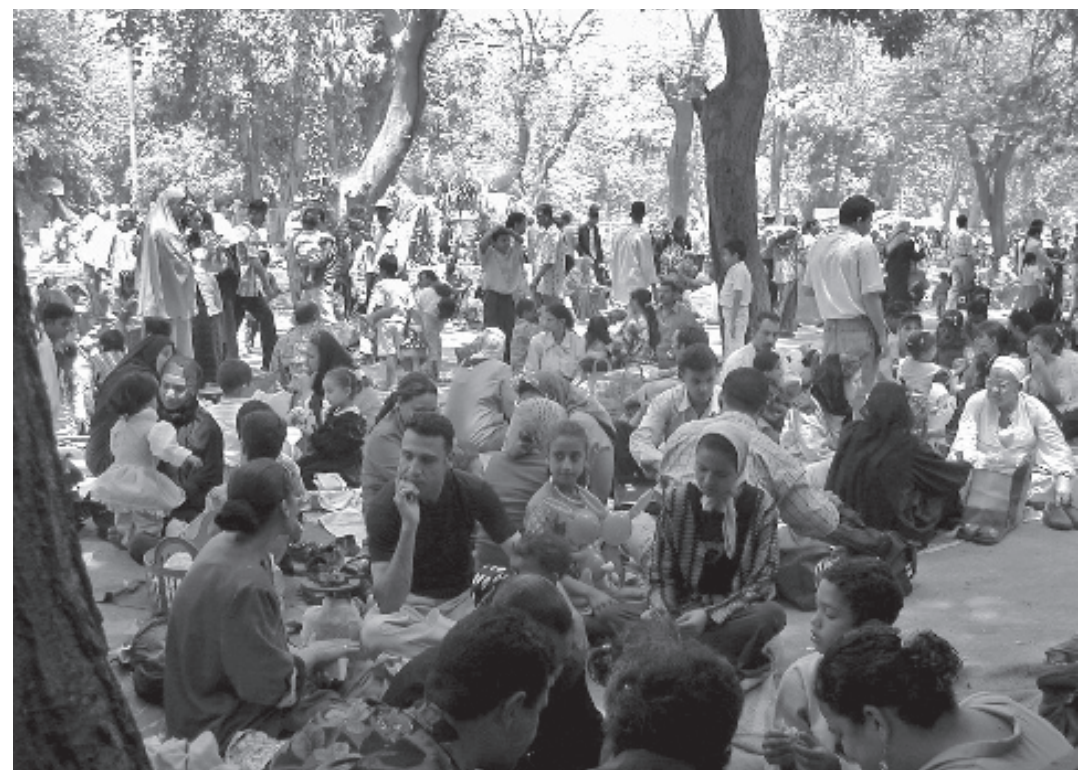

The crowds at the zoo during holidays (photograph by Vincent Battesti).

Boys sing and shout as they would not dare to do in their own neighborhoods. They whistle and sometimes move to music made by drums they bring along or their radio-cassettes. A small band of adolescents advances while loudly clapping their hands. In front of the banyan tree (helpfully labeled 'Ficus benghalensis'), they greet three headscarf-wearing adolescent girls, who are passing by in the reverse direction, with a low whistle; in reaction, the girls giggle, placing their hands over their mouths, lowering their heads toward their shoulders. The giant and venerable banyan, planted in I87I, is surrounded. Seated families occupy its base, children straddle the masterly branches and adolescents, bolstered by defiance, hang many meters from the ground, swinging from its giant aerial roots, at the risk of impaling themselves on the nearby kiosk.

If the boys borrow provocative attitudes, the girls are posed modestly to swap secrets and flirt. Groups of adolescents are sometimes gender-mixed and 


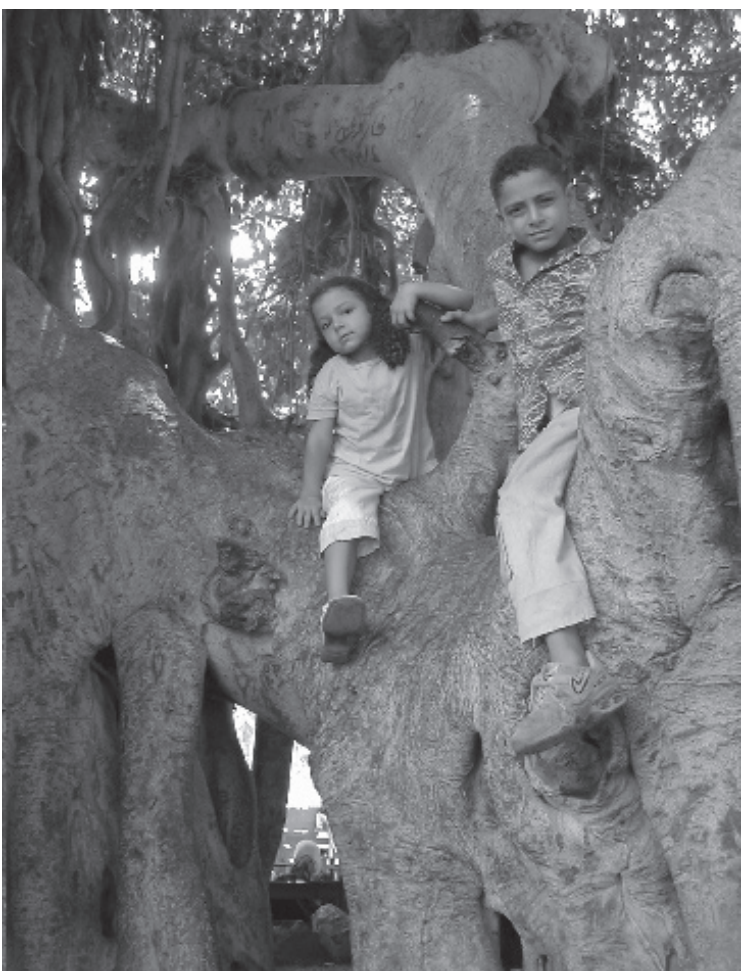

thus less oriented toward flirting and more likely to consist of couples. With the youngest 'proto-couples,' shy halting conversations are the norm, including a lot of nonverbal and tactile communications. They push one another, pinch and run after each other, boys tugging at the girls' headscarves. Despite the general press of the crowd, these mixed-gender groups struggle to frame photographs against backdrops that would breathe the calm, green enchantment of an ideal zoological garden returned to its essence. However, it seems that the entrances and grottos are the only places that might fleetingly provide this backdrop. The Zoological Garden is peppered with artificial constructions, owing to the talent of the late-nineteenth-century Ita-

Children climbing a lian and Turkish masons who reproduced grottos and mountain reliefs, crafted banyan tree dating from 1871, Giza Zoological Garden (photograph by Vincent Battesti) in stones and coral, sealed with a red glaze. The stonemasons have long been forgotten; but their work has always been greatly prized by Cairene visitors. Their artificiality deceives no one. To the contrary, it is their powerful romanticism (romansi in Cairene dialect) that excites admiration, today as it did formerly. It is not only young people but also families and small groups who have themselves photographed against the picturesque backgrounds, a decor laden with glamourous images of the past, Cairo's popularly appropriated belle-époque glory. (See El Kadi and ElKerdany in this volume for an analysis of the architecture of this period, featured in Cairo's downtown.)

It is the promenade of young lovers in search of a characteristic corner, recalling the romantic films of yesteryear. In fact, this paradisiacal place has served as the setting for many films and Egyptian serialized programs of which the most famous is the film Maw id gharam ('Appointment with Love,' Barakat 1956) (Samir 200I).

The grottos, the most striking architectural structures within the zoo, have been restored, a reminder of the good old days when 'Abd al-Halim Hafez sang 
to Fatin Hamama as he followed her along the garden's winding pathways and bridges (Shahine 1999).

The zoo is usually a family destination. But during these few intense days, groups of youth and young couples swamp the families. However, families do not cede any territory; they bring their children with them, well dressed in their 'Id gifts, little suits for the boys and little white dresses for the girlsor wearing a complete wardrobe sold under plastic in stores, with flowered hat included. In all cases, parents have taken great care to make sure that children appear in their finest attire, costumed as angelically and child-like as possible; whereas the adolescents proudly display their brand-name ' $I d$ gift outfits (Nike, Levi's, Adidas, etc., almost always counterfeit) and the indispensable accessories of the season. One can guess that parents, without being in their 'Sunday best,' have made a vestimentary effort as well. For men, pants and shirt are preferred. The gallabiya (long shirt-like garment that reaches the floor) would be gauche. Women wear dresses carefully matched with their headscarves. Women of popular quarters are identified by the way they wear their scarf knotted at the neck rather than under the chin. The appearance remains a strong marker of greater or lesser social ascension. The families circulate among the animal cages, following the children's vague desires to see the animals or to consume-ice cream, another cola, tiger or lion makeup, or an inflatable balloon in the shape of a deer or a giraffe.

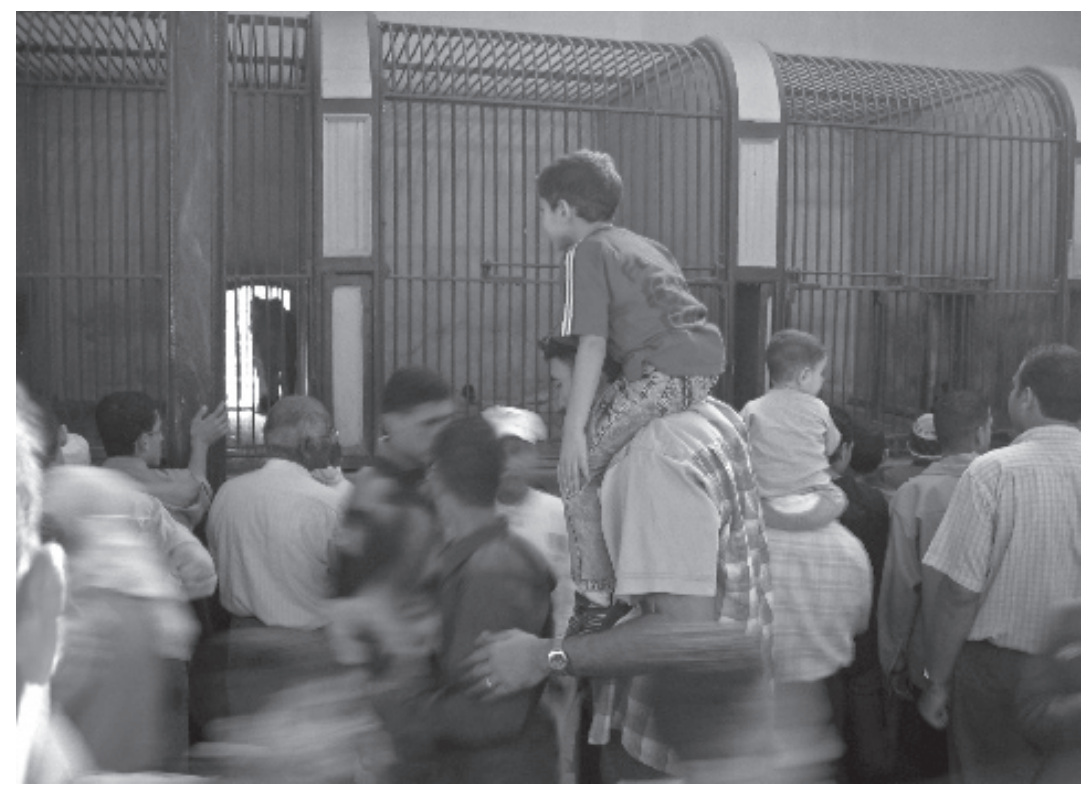

Visitors to the zoo view the caged animals (photograph by Vincent Battesti). 


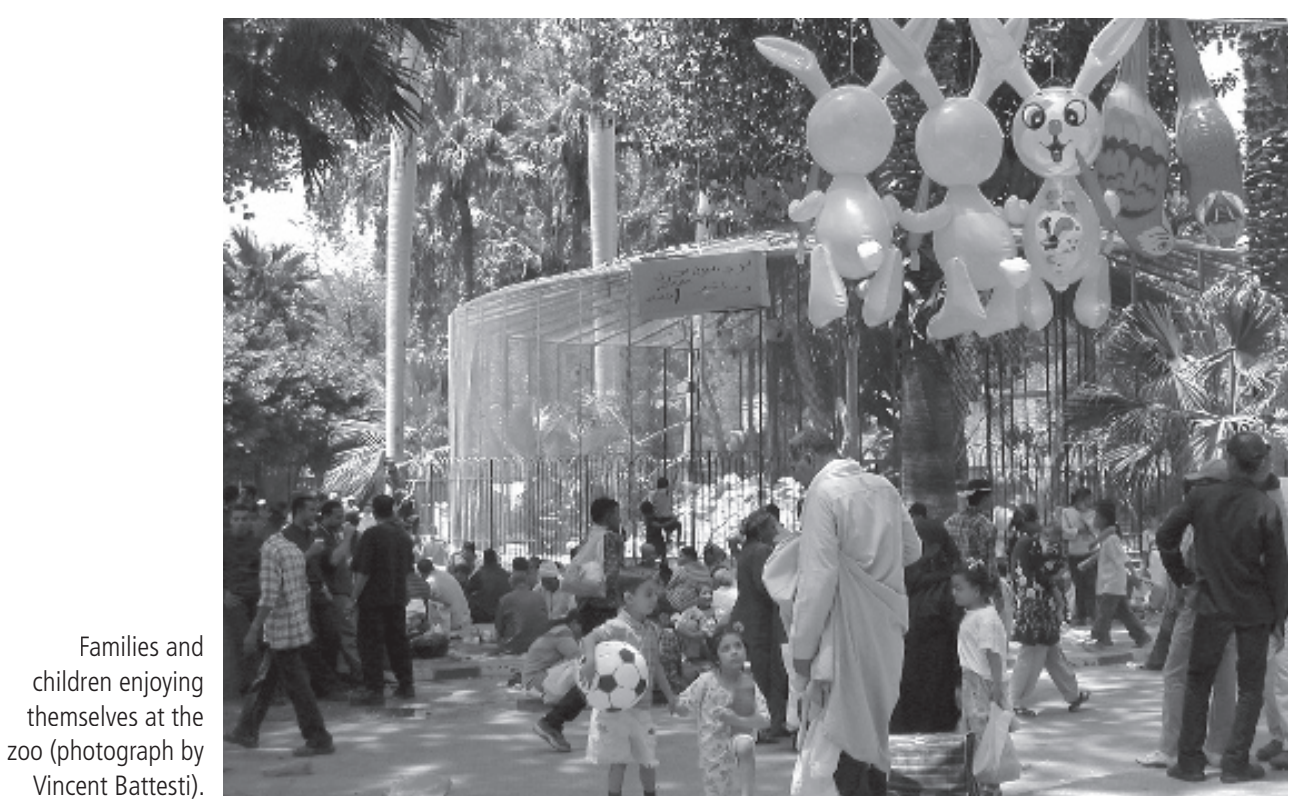

Families settle themselves on the numerous (but insufficient) benches, painted white and bottle-green, as well as in the spaces left open at the margins of the walkways. On this occasion especially, sitting on the grass is a liberty that visitors take, even against the interdictions posted on signs by the garden's administration. A tablecloth (a sheet, plastic mat, wool, or synthetic covering) performs several functions. The cloth is laid out and first, the woman-wife or mother-sits down and brings around her the children, the husband, sacks of provisions, plates, a music stand, the basket or package of food, and eventually, the football, the husband's shisha (water pipe), the stove for the tea, the children from other family groups. The density of the entire body renders the border between one family and the next almost unreadable. The tablecloth has an obvious function as a territorial marker whose integrity is more or less respected, particularly along the corridors between them. The other accessories are more mobile markers whose placement allows for negotiation with neighbors, expressed during the festival days through forms of courtesy and politeness: "Please, we'll make a place for you between us and our neighbors" (a space that the children already trample).

The press of the crowd demands often that the father or fiancé act as a border guard, bringing attention to invasions onto the little space of the family, or at least making a public display of it. The option of an even and maximal dispersion between families does not always prevail. The search for distance 


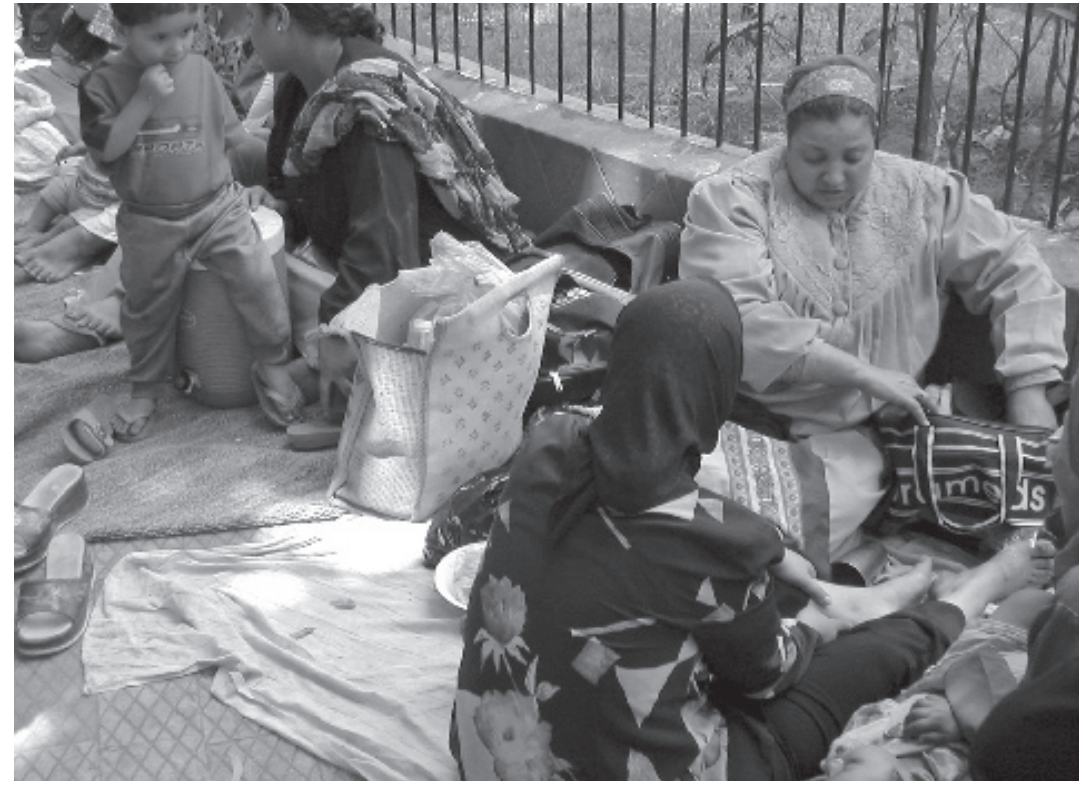

from other groups (real, without being isolated either, except for couples that are not officially engaged) is coordinated according to the requirement of finding a 'good place' (sunny or shady, dry or elevated surface, fairly near to the fountains, etc). On this small domestic perimeter of tablecloth, unfolded in a public space and refolded when one leaves, the celebrating Cairene families at the zoo manifest the signs of the pleasant and bucolic recreation of a picnic, despite possible intrusions. The mothers' and wives' first gesture is to remove their sandals or shoes, leaving them on the tablecloth. They remain barefoot through the afternoon, while regularly pulling at their dresses to avoid the immodesty of exhibiting their legs. With this space conquered, the husband can explore at a greater distance with the children, taking them to see the giraffe, for example, whose success with the children is guaranteed. Using its long black tongue, the giraffe knows how to snatch, without fault, the carrot that is extended to it amidst shouts of fright and laughter.

The public gardens are popular. These are not places a proper person could frequent. If you go there one Friday, you will see, it's impossible to go there. Cairo University student who resides in the more elite satellite city of Heliopolis, 2003.

Appropriation of zoo space is intense, a pretty confusion of generalized jostling. Practically the only beings that avoid being jostled are the animals,
Families picnicking just outside the gates of the zoo during the holiday celebrating the end of Ramadan (photograph by Vincent Battesti). 
protected behind the bars of their cages. However, other refuge-spaces exist. The garden's administrative offices, enclosed by a high wall resembling those of the grottos, conceal peaceful small buildings. These buildings open out onto a small private garden. The entrance to this space is, however, guarded by incorruptible guards dressed in blue uniforms. The zoo's cafeterias operate according to a still different statute since you have to pay and consume to remain in them. These open-air eateries are modest, but relatively exclusive spaces inside the vast public park. There is not a door to push to penetrate this space, only a few steps, at most, to climb. The limits of these spaces are clear, 'natural,' when it concerns a reconstituted rock or a duck pond; artificial when it was necessary to enclose them with a wire netting. In these relatively chic oases, one finds tables and chairs. Here, a customer does not remain standing, and one does not make oneself comfortable sitting on the floor. In addition, one is implicitly obliged to consume the refreshment sold there (food or drink, even the water-pipe shisha which is de rigueur for the fathers of families). These products also allow the establishment to prosper, charging scandalously high prices that dissuade the majority of visitors from eating there.

Guéziret Al-Chay (the Island of Tea) is a café-restaurant that is situated at the edge of one of the zoo's lakes on which there are swans. The café is also located in the middle of a collection of very old and rare plants and trees. There, one serves you tea and a repast, at a good price. In front of you, you can contemplate the calm waters of the lake where swans, ducks, and geese of different colors splash about. And behind you, it is green. State Information Service 2001.

The price of entry to the zoo, held down to twenty-five piasters (about \$o.05) allows everyone, including the popular classes, to buy a ticket. But the prices charged in the cafeterias are of a completely different order, and probably of a completely different logic. With that said, at the zoo the happy few during festival times already fill a good number of the available tables. These are families (generally nuclear families with one or two children), but also some adolescents whose pocket money allows them to enjoy this setting. Posing or seated, looking for adventures of flirting, forms of communication build on a repertoire of ironic, theatrical mimicry and gazes. The difference between the level of human density on pathways and spaces of the zoo outside the café, and sparseness of the internal space of the cafeteria, is flagrant. However, no one dares to violate these sanctuaries of relative calm without considering the steep price for penetrating this exclusive realm, only the unconscious actors of the 'social comedy.' Meanwhile, the café's waiters quickly capture 
those children who rush into the enclosure, attempting to contain them at the exterior of this strangely full bubble, but which seems half empty, compared to the average density of the garden. The crowd's movements can, however, overflow the cafeteria security forces. When a rumbling noise started a rumor that some lions had escaped the nearby cat compound, the panicked crowd was able to flow into these exclusive spaces without much resistance from the guards or patrons.

The crowd visiting the public and Zoological Garden during the big festival days is compact, but composed of hundreds of thousands of units, a colorful, composite crowd. What brings all of these visiting individuals together, gathered in the same space at the same time? A religious (Muslim) festival? Not really-there are many Coptic Christians among them. A holiday on the calendar is only perhaps an opportunity. (See Elshestawy in this volume for further discussion of the way popular classes use squares near the mosques of Sultan Hasan and al-Rifa'i, and the way in which the government has tried to limit public access to them, supposedly for the benefit of international tourists.) It explains nothing about the choice of the public garden or about the practices occurring at the heart of it.

Respondent: As for me, I come here with my family, because I find the garden beautiful. The whole entirety is wonderful: the ambiance [al-gaww], the water, the ducks... It's beautiful because it is zahma [very crowded, densely occupied]. If it weren't zahma, it wouldn't be beautiful. We like to see the people. It's an occasion to see everyone, how they are, how they act, how they're dressed... In fact, this is what getting out on the town is all about.

Author: Here in the Zoological Garden, do you come to see the animals or the people?

Respondent (laughing): In fact, both! Interview in the café with a businessman in his late forties from Alexandria, visiting the zoo during a holiday, 2003.

The key word: al-gaww, 'ambiance,' gives reason enough. "'Alashan nighayyar al-gaww" (so we can change our mood, our ambiance). But "to change ambiance" in relation to what? To the quotidian, to the quarter of one's origin? This poses the question of the social and geographic origins of the users of the Giza zoo. How can we categorize these visitors without defining them simplistically? People from Cairo, the popular classes - these are crowds of anonymous people who observe one another. But this is a type of crowd that the sociologist has trouble categorizing and defining. The definition of Egypt's 
popular classes as a social category is a delicate matter. Should its definition be delineated in opposition to a much wealthier class, which is too easy to identify, or in distinction from the middle class, which is too difficult to circumscribe given the blurriness of consumer identities? ${ }^{1}$

The popular classes that use the public space of the zoo are also hard to define because they comprise an obvious diversity in terms of revenues, levels of life, social positions, educational levels, and urban-neighborhood origins. The hypothesis of Egyptian economist Galal Amin is that the Egypt of these last fifty years has provided new avenues for social mobility and that certain elements of the popular classes have experienced an ascent toward the top (2000). In Egypt, it is trendy to equate the vulgarization of public morals with the rise in power and presence of popular classes. Demographic growth, bursting of the boundaries that geographically and socially divide Cairo's worlds, public space has undergone profound change, but segregation continues.

\section{Public Spaces: Parks and Downtown Cairo}

An early jewel of the modernization of Egypt's capital city, the Giza Zoo is now marked as a nostalgic last vestige of the greenery that characterized agricultural hinterlands that once surrounded Cairo. Under the supervision of the minister of agriculture, the zoo is technically administered as fertile land in the core of Greater Cairo's downtown, submerged between apartment towers, Cairo University, and the traffic of the central avenues. Since the mid-twentieth century, the zoo has become surrounded by the neighborhood of Duqqi. The zoo is enclosed but porous; unlicensed vendors work through the bars of the iron fencing. The zoo is a destination; one moves around there. Buses, microbuses, and boat-buses serve it abundantly: mass transportation for the visitors who, in the majority of cases, do not have access to an automobile. This is another index of the social origin of the strollers who ordinarily reside in the more distant, poorer quarters. If the Zoological Garden is disdained by tourists in favor of the classic tourist sites of the capital (the Pyramids of Giza, the Citadel, the Egyptian Museum), the popular classes approve of it wholeheartedly. Egyptian interlocutors learn with amazement that non-Cairene visitors frequent the zoo, which they think of as their 'secret garden.' It is not so much the animals that draw the visitors as it is other people, and a setting in the city that offers possibilities of encounters, observations, and a certain density of people, away from the scorn of the wealthy or of immediate neighbors.

One could draw up a map of Cairo showing pedestrian density and urban ambiance, the window-shopping or lazy strolls, innocent flirtations, and children's games. It would then be necessary to take a census of all the 
public gardens, squares, commercial and pedestrian streets of wust al-balad (downtown), the shopping malls, the corniches of the Nile and its bridges, and the up-river parks and ferries to al-Qanatar where families and couples go during the weekends (see Abaza 200I, and Elsheshtawy and Abaza in this volume, for further discussion of consumer practices at shopping malls). This would be a geography sensitive to the pleasures of urban pedestrians, of strolling, chasing, and jostling.

During spring 2003, local newspapers ran headlines declaring that the Egyptian capital had taken from Mexico City the honor of being the most polluted megalopolis in the world. Cairo's residents did not wait for this record news to reclaim more green spaces. During the coolest hours of summer evenings, when public gardens are closed, Cairenes look for anything that approaches a garden. Families picnic on the grassy underpasses of bridges or meager lawns of a few traffic circles, encircled by the polluting traffic jams. This search for 'green' is global, as is its discursive manifestation, but its expression is locally specific to Cairo/Giza. ${ }^{2}$ For example, the Japanese garden of Helwan and its design have not visibly obliged Cairo's residents to the Zen practice of quiet repose and reflection since it was inaugurated in $1993 .^{3}$

Use of the public space by Cairo's popular classes is partially constrained by a history that should be explored briefly. Two kinds of Cairene popular public spaces attract our attention: the public garden and the downtown street. One of the most remarkable phenomena of the last fifty years directly concerns the occupation of public space. The Egyptian and cosmopolitan bourgeoisie who had occupied downtown Cairo for generations before the anticolonial revolution of Gamal 'Abd al-Nasser and the Free Officers in 1952 largely abandoned it. These downtown quarters of Haussmannian inspiration had been the middle class and elite's domain of choice since the second half of the nineteenth century.

However, the new bourgeoisie-and in particular the nouveaux riches of the Infitah (economic overture of President Sadat during the I970s) made themselves comfortable elsewhere, to the west, the north, and the south of downtown Cairo. (See Denis in this volume for a discussion of the abandonment of the city's urban more by the middle and upper classes, manifested most concretely in the explosion of gated communities in the desert.) Concomitantly, the place was occupied by the more modest strata of the population. Popular classes invaded at least the sidewalks, if not the residences of downtown. From the mid-nineteenth through the mid-twentieth centuries, the area was frequented by a bourgeois elite parading through the shopping arcades, gardens, and promenades in elegant dress under the shade 
of small parasols. But since then, downtown has changed into a dense and popular place of excursion for window-shopping and people-watching by another class of people.

[Families of the poor quarters] began to look at each other. They wanted to go out on the town like the others [the bourgeois]. They wanted to take walks, so they went to the gardens [gana'in], to the cinemas, the public parks [hada'iq], places like that.... They learned [to go out on the town]. Forty-year-old woman from a popular quarter in Islamic Cairo, 2003.

Do these practices imitate the ethos of the (former) dominant classes? Not completely, because the substance of the practices is quite different. Formerly, the accent was placed on appearance, on displays of social distinction and individuality. But what is of prime importance today during downtown strolls and walks in the gardens is more the search for conviviality and an ambiance of urban animation. One leaves one's quarter of residence to go to those parts of the city where one is sure to find that vibrancy that will be worth the trip. These Cairene residents create and seek precise ambiances and participate in a certain unique spectacle of consuming the city, which itself is watching. The excursion to the public garden has experienced the same history as that of the transformed downtown. A desire to self-segregate caused the wealthier classes to migrate to other horizons, leaving the gardens and heading for their new members-only sporting clubs. The membership charter of one of these clubs (nadi) of very British inspiration grants the privilege of access to reserved gardens, reserved activities, and equally exclusive ways of using these things.

Interviewer: Where do you go during your leisure time?

Female respondent: To the clubs, the Nadi Gazira for example, to see friends. And I also go to certain malls to shop....

Interviewer: Never to the zoo?

Female respondent: No, never to the zoo, nor to the public gardens. The public gardens are places for the popular classes. Why would we go to places, anyway, where our friends did not go? The popular classes in all ways, even if they have the means to frequent the clubs, would never dare to go there: they would not feel at home.

Interviewer: Why?

Female respondent: Because they need to enjoy themselves by having picnics with a casserole of mahshi [stuffed vegetables] and to eat on the ground. That isn't possible in the clubs, where there are tables, chairs and restaurants. 
Male respondent: And also they would not feel at ease, because some people, not we, but some people look at them with disdain. The security agents will ask them what they have come to do there: "You, you are a member?!" By their dress, one would easily see that they are not of the group. Interview, two Cairo University students from Heliopolis, 2003.

Criticism of the public gardens is often severe among representatives of the wealthier strata of society who express regret about the 'invasion' of public spaces by the masses who "do not know to act, who are not respectable" (muiaddab). All Cairenes objectively consider distinctions between classes of public space in their discourse. The wealthiest say they do not mix with the poorest of society, because they fear crime, insults, filth, contamination, and vulgarity. The popular classes say they fear feeling "out of place," standing out. For all, it is about attempting to preserve one's lifestyle among others who do not understand their codes. This social disjunction is not a recent invention. But the coming out of the populist classes is.

At the end of the 1960s people did not go outside. The people in popular-class families stayed in their homes. What does that mean? Girls were forbidden to go out. Young men went out rarely, and if they liked to go out, they went out to sit down at a café. These public gardens [hada'iq], downtown and all these things were only for the bourgeoisie. It was their own place. At the beginning of the 1970s, then people started to go out.... [But until then,] they did not leave their quarter [mantiqa]! Not much. They went to visit each other in their houses. That's all. But [for them] there were no public gardens; there were no cinemas. ... The bourgeoisie went to the cinemas; the bourgeoisie went to the public gardens, and to the casinos, the cabarets-the bourgeoisie, they went there. Interview, forty-eight year old married woman from Darb al-Ahmar, a popular quarter in Islamic Cairo, 2003.

When the popular classes started going out, the wealthy strata of Cairo took refuge in exclusive leisure spaces and in gated communities. The bourgeoisie's critique of the current condition of public spaces highlights the divergence between today's popular practices and appropriations in the public gardens and their initial intended purposes, to stimulate elite national conceptions of modernism, hygiene, and morale. Historically, the first appearance of a modern public garden in Cairo, in 1837 , was by fiat of Prince Muhammad 'Ali. The pasha created for the public of Cairo (in particular, the European public) a promenade above Shubra Avenue. It transformed what was a swampy lake, Birkat al-Azbakya, into a park "in the European manner." A 
double concern, both hygienic and moral, governed this choice: Muhammad Ali, very concerned with questions of hygiene, wanted to cleanse the lake, which fluctuated with the tides of the Nile. He also wanted to substitute the debauchery of nearby pleasure gardens (cafés, prostitutes, and peddlers) with a "healthy leisure activity that was both moral and modern" (BehrensAbouseif 1985). Moral and spatial hygiene, already a global metanarrative, was one of the principal nineteenth-century arguments for creating green spaces in the urban milieu. "Trees increase air circulation, the diffusion of light and, especially, they absorb the miasma that escapes from the entrails of men and factories" (Nourry 1997). Cairo's urban promenades (gardens, boulevards) or periurban paths (the vast gardens of al-Qanatar) aimed to please and to raise to global stature the new bourgeoisie of Cairo.

In all my interviews, consciousness of the major social changes during the twentieth century, between the I960s and the beginning of the r970s, becomes evident. For some groups, in the I96os they did not yet go out to the zoos and gardens, but in the I970s they began to venture into them. For others, in the I960s they remember strolling in the zoo and parks. But then in the r970s they stopped going. One public replaced another, and the new users had the numerical advantage.

There is that anecdote of Winston Churchill who said that a desert entrusted to Jews became a garden but a garden entrusted to Arabs became a desert. It is quite nasty, but history has proved him right. What has become of the zoo and Azbakiya [the oldest public garden in Egypt constructed at the beginning of the foundation of the modern city]? Forty-year-old Egyptian male industrialist interviewed at his private club, Nadi Muhammad 'Ali, 2003.

The burguwaziyin (bourgeois) are upset by reports of the 'degradation' that these spaces have undergone. If this sometimes rises to the level of consternation, it is because the change is radical in the way that public space is occupied. The public gardens that were originally conceived in the spirit of public health, now 'function' for the populist classes only if the ambiance is good, notably if the density is equivalent to the teeming neighborhoods where these populations reside.

Al-Qanatar was not so interesting when we were there. Why? When we were there, we were alone; there weren't people! It wasn't beautiful, in fact. We weren't content because there weren't lots of people. The people give the breath of life [a soul] to the place.... This is the most important thing. If the place does not have people, 
[even] if the place is very beautiful, then it's not beautiful. You feel it. [At the zoo], there is life, that is to say, there is movement, there is life, and that's beautiful, that is very important, it means space, relaxation, it is very important. Twenty-fouryear-old woman from Darb Al-Ahmar at the international garden (al-Hadiqa al-Dawliya), Madinat Nasr, a suburb of Cairo, 2003.

Even if one considers parks and gardens, to a certain extent alternative spaces to the city (Gillot 2002), the activities conducted by the popular classes there and downtown today are similar, and these places had the same fate. For the popular classes, frequenting both kinds of space represents breaking out of the constraints of cramped lodgings in their home residential quarters. The mulids (festivals celebrating saints' birthdays) of Cairo are known to bring together the popular classes of the city (and sometimes of a whole province), and to be cathartic and maybe liberating. (See Madoeuf in this volume for a discussion of mulids and sacred, public space in Cairo.) The life of the popularly occupied zoo and parks is less known and less described. During holidays, these venues bring together at least as many people as mulids doin particular during the two 'ids (al-Fitr and al-Adha) and the spring festival (ahamm al-nisim). While the mulids revisit the tissue of the old quarters, holidays in the zoo or in public gardens are space-times that occur outside of the old popular city. The urban ambiance of recreation that is created there resembles the known ambiance of the mulids, and yet is at the same time different because it blossoms under different conditions.

\section{Programs and Adjustments to the Zoo}

The purview of a public space takes its substance first from its originally intended use, and second from its successive redefinitions (which never really annul the first agenda). The zoo is situated in Giza, now a residential extension of Cairo across from the Nile island of Roda. During the Mamluk era, Giza hosted a palace and royal gardens; in the late nineteenth century it became a country suburb. The Zoological Garden lies on the edge of the Nile, away from the overpopulated quarters of Cairo, but in proximity to downtown. From I867, another garden with a lesser surface area (fifty Egyptian feddans) existed there, named the Garden of Delights. This was the garden of the royal household during the reign of Khedive Isma'il (1863-I879). The gardens were populated with animals from the royal collection for the prince's concubines (Delchevalerie I899). By the time the zoo passed into public hands, at the end of the I870s, it was somewhat deserted. Gradually it was reorganized in order to properly receive the public on I March I89I (Keimer 1954). 
The administration of the Zoological Garden attempted to adapt itself to the evolution of its public as much as it attempted to adapt its public to the zoo. Between what the administration would wish for in the behavior of its visitors and what the public offered, there was and is always a gap, as daily practices reappropriate and socially resignify place. If we follow the terminology of Isaac Joseph, we frame this process as fitting between plans and dispositions (1998). It is essential to grasp the city dweller in her/his mutually constitutive relationship with the space in which s/he evolves. We must "think together about plans (agendas or 'programs') that develop or institute the norms of usage and also of dispositions (social and technical competences) that adjust or redefine these norms of usage in a singular situation" (Joseph 1998). These adjustments, these redefinitions of the garden by its public, are unavoidable. People are always reappropriating a place, "too much" as some authorities who prefer to close the gardens, or parts of it, would say (because the public would run the risk of ruining them). Zoo authorities particularly worry about certain zones (cactus gardens, tunnels, al-gabalaya al-malaki, grottos) that lend themselves too easily to discrete moments of tenderness. The first authority at this level is the lock; the second, the cohort of guardians - very nice fellows actually, who enter with a blasé whistle-blow that would never really convince any picnicker to renounce his space on the lawn, and who then invites families to feed an ostrich, a sea lion, or an elephant. Police forces are present when the risk to public order is deemed to be real, during mass outings and on festival days. Tolerance (or impotence) seems to prevail but remains contained within the walls of the garden. As a policeman posted at the Zoological Garden said, "During the four days of 'Id, it will be like that. You should return after the festival. Then it will be calmer."

The zoological character of the Zoological Garden almost seems incidental to the declared motivations of visitors. However, in terms of the originally intended agenda, it is a scientific exhibit, and it seems that priority was first given to the scientific mission of the establishment rather than to the creation of a leisure-time activity for its visitors. From I898 to 1924, under the direction of Stanley Smith Flower, (an English zoologist and son of another eminent zoologist), a policy of increasing collections was established and is still maintained. "This discourse of scientific utility is always accepted by other social groups because it theorizes and justifies, by its requirement of knowledge and of rational use, the aspiration of the elites, and then of all European society with its inventory and appropriation of the world" (Baratay 1998). The zoo is rapidly developing concerns for attracting and pleasing the public. There has developed, in Cairo as in Europe, a pedagogic will since the 
end of the twentieth century, or rather "a vulgarizing lens" (Baratay 1998). The interest of the public has not waned. In 1899 there were 43,567 visitors and ten years later (I909) the number climbed to 217,735 (Flower I9IO). Newspapers closely witness the arrival of new animal residents (Keimer 1954).

The zoo is better than other gardens in Cairo because there are lots of people, and also because there are animals and there are really always visitors, even if one is walking in fact. Even if one has a great deal of time [to spend] in the garden he/she will not be able to see it all. There will still be a lot of things that he/she has not seen and he/she will need to return to see them. There is always something new to be seen. People and animals actually. Young woman from Islamic Cairo, 2003.

This public space, the zoo, has survived and reflects more than a century of Cairo's vicissitudes. The place has been gradually transformed; the public and its mores have mutated. Can one still talk about a concordance between the content and its containing elements? The garden was indeed conceived of as a collection and an exhibit of animals, according to the models of the last century. With that said, various ecological pressure groups interested in animal rights (in particular, American groups of this kind) exhort us to not believe this concordance and protest regularly against the 'detention' conditions experienced by Cairo's zoo animals.

Oh, there are lots of lovely cafeterias and beautiful gardens, and the grottos have been repaired. It's great-unless you're an animal. Richard Hoath, former member of the Born Free Foundation, interviewed by Ghazaleh 2000.

Today, the Zoological Garden at Giza, ignored by the majority of travel guides that prepare tourists for their discovery of Egypt, is adorned with superlatives in official discourses and is ranked among the great green spaces that contribute to the urbanity of a modern city. This is one of the world's great zoos, with a huge surface area of more than forty-eight Egyptian feddans. It is also one of the oldest (opened to the public in I89r). Without a doubt, it would have been one of the most beautiful. The zoological park of Giza is consecrated as "the most celebrated green space of the capital," for its animals but also for its plants, and for being a place to promenade and not solely to visit animals in cages:

Those strolling, tired from crossing the great expanses of the garden, may relax at the Guéziret Al-Chay (literally translated, the Isle of Tea). It's an escapade in 
itself, after all the excitement that usually accompanies the sight of wild and other animals. State Information Service 200I; Samir 200I.

If, since the beginning of the 1970s, practices in the public gardens have greatly changed, the relative tolerance practiced by the police services there (or their outflanking) implies a relative balance between programs and dispositions. Certainly, the initial designs of the Zoological Garden, that is its scientific and pedagogic value, have had to be reevaluated. During the 1950s, one could still write:

[A] zoological garden is no longer uniquely a place for walking and enjoyment, it is a great book of natural history for people desirous of instructing themselves, for the entire nation, as well as for school children who, accompanied by their masters, go to the 'zoo,' and for the worker, the fellah [peasant], the student, the functionary, etc.". Keimer 1954.

Today, we do not hear of didactics, but of love. The director of the Egyptian Zoological Gardens, Mustafa 'Awad, will say that he considers one of his objectives to have succeeded, because "today, there is a kind of love between the public and the animals" (interview, 2003). He wishes to explain to the public how to treat animals well and to lead the public to love them. He is not lacking in photographic resources in support of his assertions (children in the arms of a monkey, etc.). At Cairo's zoo, keepers insist that the visitors feed the animals (from the end of a stick of wood, accepting tips from visitors), while in other zoological gardens of the world, it is 'forbidden to feed the animals.' Indeed, observing the keepers, it is possible that certain animals are, for the most part, fed this way. Seals, sea lions, ostriches, elephants, hippopotami, monkeys, giraffes, and ducks are rewarded with food for demonstrating their training and for obedience to guards' cues. Surrounding visitors are impressed that the beast obeys the keeper-the hippopotamus opens his huge mouth, that the seal holds himself erect or he emits a series of groans believed to be answers to a question posed. The experience may resemble a circus show of trained animals and the keeper is more than a little proud (his falsely blasé attitude betrays him). The Egyptian zoo, is it a place for exhibiting wild animality or domesticated pets?

A priori, it is the keepers' demonstration of a level of control over the animals that is not matched by the guards' level of control over human guests (this is reminiscent of Haudricourt's reflection on the conjunctions between ways of treating animals, plants, and others [1962]; see also Battesti 2004). 
"Domestication is the archetype for other types of subordination" (Thomas 1985). The zoo administration's discourse of love, the proximity between animals and visitors, the practice of rewarding trained domesticated behavior in animals - is this a 'program' thought out as such by the zoo's administration or is it an opportunistic adaptation of adjustments and redefinitions of popular contemporary uses? Even if the zoo director has abdicated a part of his authority and has offered direct access to the animals it is understandably successful, altering its mission to changing use patterns, pleasures and concepts of beauty and sociability.

\section{Conclusion}

The appropriation and 'reanimation' of the Zoological Garden of Giza marks the invention of a new kind of unique urban, recreational ambiance. The uses of the zoo have evolved under the influence of two great movements. On the one hand, zoo planners and administrators have designed a mission for the zoo, planning and directing the behavior patterns of guests, animals, and guards, guided by the metanarrative of what a zoo ought to be and how green space ought to be used. On the other hand, the zoo has come to embody the dynamic articulation of density and vibrancy, and to serve as a stage for plays of domesticity, flirtation, and theatricality. When the popular classes are at the zoo, it belongs to them. They did not reproduce the bourgeois ethos that used to prevail there; to the contrary, they have partially imported, expanded upon, and reinvented the urban models of their quarter of origin: autocontrol and urban ambiance in a festive crowd. Acting as coproducers along with the zoo's authorities (sharing readability, panoptic feature concern), Cairo's popular classes have staged and articulated new public norms of sociability, urbanity, and collective beauty that have made the Giza Zoological Garden into an icon of Egypt's newly appropriated popular public spaces.

\section{Works Cited}

Aga Khan Trust for Culture. 200I. The Azhar Park Project in Cairo and the Conservation and Revitalisation of Darb al-Ahmar. Geneva: The Aga Khan Trust for Culture.

Amin, Galal A. 200o. Whatever Happened to the Egyptians? Changes in Egyptian Society from 1950 to the Present. Cairo: The American University in Cairo Press.

Abaza, Mona. 20or. "Shopping Malls, Consumer Culture and the Reshaping of Public Space in Egypt.” Theory, Culture \& Society I8 (5): 97-I22. 
Baratay, Eric, and Elisabeth Hardouin-Fugier. 1998. Zoos, Histoire des jardins zoologiques en Occident, XVIe-XXe siècle. Paris: La Découverte.

Battesti, Vincent. 2004. "Odeur sui generis, Le subterfuge dans la domestication du palmier dattier (Tassili n’Ajjer, Algérie).” In Anthropozoologica-Domestications animales: dimensions sociales et symboliques, eds. Pierre Bonte, Anne-Marie Brisebarre, Daniel Helmer, and Hasan Sidi Maamar, 30I-309. Paris: Publications Scientifiques du Muséum.

Behrens-Abouseif, Doris. 1985. Azbakiya and its Environs: From Azbak to Ismầîl, 1476-1879. Cairo: Institut français d'archéologie orientale.

Beyhum, Nabil, and Jean-Claude David. I997. "Du souk à la place, du citadin au citoyen, Espaces publics dans les villes arabes (au Moyen-Orient).” In Sciences Sociales et Phénomènes Urbains dans le Monde Arabe, Actes $d u$ colloque de l'Association de liaison entre les centres de recherches et de documentations sur le monde arabe (ALMA), eds. Muhammad Naciri and André Raymond, 193-202. Casablanca: Fondation du Roi Abdul Aziz AlSaoud pour les études islamiques et les sciences humaines.

Central Agency for Population, Mobilization, and Statistics (CAMPAS). 2000. Household Income, Expenditure and Consumption Survey, 1999/2000. Cairo.

Delchevalerie, Gustave. I899. Les promenades et les jardins du Caire, avec un Catalogue général détaillé et les noms scientifiques, français et égyptiens des Plantes, arbres et arbustes utiles et d'ornement cultivés dans les champs et les jardins et notamment dans les anciens jardins vice-royaux et khédiviaux de l'Égypte sous la dynastie de Méhémet-Aly au XIXe siècle de J.-C. Chaumes: G. Delchevalerie.

Dumazedier, Joffre. I998. "Loisir.” In Encyclopaedia Universalis. Paris: Encyclopaedia Universalis France.

Flower, Stanley S. I9ro. Report for the Year 1909 (Eleventh Annual Report), Zoological Gardens, Guizeh, near Cairo. Cairo: Public Works Department, Government of Egypt.

Ghazaleh, Pascale. 200o. "Richard Hoath: The Call of the Wild." Al-Ahram Weekly, 23 March.

Gillot, Gaëlle. 2002. Ces autres espaces, Les jardins publics dans les grandes villes $d u$ monde arabe: politiques et pratiques au Caire, à Rabat et à Damas. Ph.D. diss., Université François Rabelais.

Haudricourt, André-Georges. 1962. "Domestication des animaux, culture des plantes et traitement d'autrui." L'Homme 2 (I): 40-50.

Joseph, Isaac. 1996. "Les compétences de rassemblement, Une ethnographie des lieux publics." Enquête 4: 107-22. 
1998. La ville sans qualités. La Tour-d'Aigues: Édition de l'Aube.

Keimer, Louis. 1954. Jardins zoologiques d'Égypte. Cairo: Éditions des Cahiers d'Histoire Égyptienne.

Nourry, Louis-Michel. 1997. Les jardins publics en province : espaces et politique au XIXe siècle. Rennes: Presses universitaires de Rennes.

Samir, Amira. 200r. "The Tea Island, un coin de calme et de beauté." Al-Ahram Hebdo, I8 December.

Shahine, Gihan. 1999. "Life Behind Bars." Al-Ahram Weekly, ro June.

State Information Service. 200I. "The Tea Island, un coin de calme et de beauté." Lettre du Caire, I8 Dec.

Thomas, Keith. 1985. Dans le jardin de la nature, La mutation des sensibilités en Angleterre à lépoque moderne (1500-1800). Paris: Gallimard.

\section{Notes}

I Based on the Household Income, Expenditure and Consumption Survey conducted by CAPMAS (Central Agency for Population, Mobilization, and Statistics) in $1999 / 2000$ (2000), and according to François Ireton's analysis (personal communication with author, CEDEJ, Cairo, 28 September 2004.), the Egyptian urban population can be placed in three categories: the "poor and populist classes" (less than LEI2,000 of expenses per household, per year), the "middle classes" (between LEI2,000 and LE29,999), and the "easy or wealthy classes" (LE3O,OOO or more). The first category comprises 68.I2 percent of households (63.83 percent of the population), the second, 27.3I percent of households (3I.4I percent of the population), and the third, 4.56 percent of households (4.76 percent of the population) in the urban zone. Thus, urban zones have a real 'middle class': real in the sense that it represents more than a quarter of the households and nearly a third of the population. However, their expenses are still limited (\$r.oo was actually worth about EGP6.20 in 2000).

2 In Autumn 2004, large billboards on top of skyscrapers advertised Heineken, asserting "We need more green in the city" (green is the color of the Heineken brand). In 1992 the Aga Khan Foundation made the same observation while deciding to offer a gift to the governorship and residents of Cairo, for the anniversary of the Fatimid foundation of Cairo. It was a large public garden (but one at which one had to pay, as always). Al-Azhar Park opened during autumn 2004 (Aga Khan Trust for Culture 200r).

3 The ginayna yabaniya is officially named "Tokyo Garden." It is a large park, situated in Helwan, a southern suburb of Cairo. It was offered by Japan on the occasion of the declaration of the twinning of the capital cities of Tokyo and Cairo. 